\title{
1922-1956 годы. Нереализованные проекты развития центрального композиционного ядра Москвы на примере Аллеи Ильича. Часть 1
}

\author{
С.Б.Ткаченко, МАРХИ, Москва
}

Теоретические и практические аспекты влияния нереализованных градостроительных решений, концепций и подходов на архитектурно-планировочное развитие городов являются востребованными для научного поиска. В работе рассматривается Аллея Ильича - часть Кремлёвского полукольца, начинающаяся от площади Дзержинского и заканчивающаяся районом строительства Дворца Советов. Оценивается градостроительная роль концепции Аллеи Ильича - нереализованной, но оказывавшей реальное влияние на территориальное планирование Москвы. Возникшая по программе увековечения памяти В.И. Ленина, Аллея Ильича фигурировала во многих московских градостроительных концепциях и проектах 1920-1950-х годов: в конкурсах на Дворец Советов, Парк культуры и отдыха, дипломных работах студентов архитектурного факультета ВХУТЕМАСа и Московского архитектурного института, проектах реконструкции ансамблей центральных площадей столицы, Генеральном плане реконструкции Москвы 1935 года. Концепция Аллеи Ильича эволюционировала вместе с изменением градостроительной политики - от «романтизированной схемы» до проектов радикальной перестройки центра Москвы, «ансамбля ансамблей». Практически ни одна из концепций Аллеи Ильича не была реализована в завершённом виде. При исследовании в качестве временно́й шкалы применена периодизация московского градостроительства, основанная на ретроспективной оценке формирования планировочной структуры города в увязке с социально-экономическими и политическими факторами влияния. Изучение влияния нереализованных проектов на эволюцию городов и городских сообществ при формировании пакета сценариев социально-экономического и территориального городского развития даёт возможность использования возрождённых и актуализированных творческих концепций в реальном проектировании. Исследование сопровождается ранее не публиковавшимися материалами проекта реконструкции центра Москвы, выполненными в мастерской-школе И.В. Жолтовского.

Ключевые слова: Аллея Ильича, Дворец Советов, градостроительная планировка центра Москвы, площадь Свердлова, Манежная площадь, нереализованные градостроительные проекты

Unrealized Projects of 1922-1956 for the Development of the Central Compositional Core of Moscow on the Example of Ilich Alley

\section{S.B.Tkachenko, MARKHI, Moscow}

Theoretical and practical aspects of the impact of unrealized urban planning solutions, concepts, and approaches on the architectural and planning development of cities are relevant for scientific research. The paper considers Ilich Alley - part of the Kremlin semicircle, starting from Dzerzhinsky square and ending with the construction area of the Palace of Soviets. The urban planning role of the concept of Ilyich's Alley is evaluated - unrealized, but it had a real impact on the territorial planning of Moscow. Caused by the program of perpetuating the memory of Lenin, Ilich Alley appeared in many Moscow urban concepts and designs of the 1920-1950s: in the competitions for the Palace of Soviets, the Park of culture and recreation, diploma works of students of architectural faculty of the VKhUTEMAS and at the Moscow Architectural Institute, the projects of reconstruction of ensembles of the Central squares of the city, the General plan of reconstruction of Moscow of 1935. The concept of Ilich Alley has evolved along with changes in urban planning policy - from a "romanticized scheme" to projects of radical reconstruction of the center of Moscow, "ensemble of ensembles". Almost none of the concepts of Ilich Alley was implemented in a complete form. The study uses the periodization of Moscow urban planning as a timeline, based on a retrospective assessment of the formation of the city's planning structure with socio-economic and political factors of influence. The study of the impact of unrealized projects on the evolution of cities and urban communities in the formation of a set of scenarios for socio-economic and territorial urban development makes it possible to use revived and updated creative concepts in real design. The study is accompanied by previously unpublished materials of the project for the reconstruction of the center of Moscow, made in the workshop-school of I.V. Zholtovsky.

Keywords: Ilyich alley, Palace of Soviets, urban planning of the center of Moscow, Sverdlov square, Manezhnaya square, unrealized urban development projects.

Роль неосуществлённых концепций и проектов преобразования площадей привлекает внимание архитекторов не только с точки зрения истории градостроительного искусства. Подавляющее количество последующих проектов опирается на предыдущий материал. Проектировщики анализируют возможные сценарии развития городского пространства, используют концепции прошлого, преломляя и актуализируя их в соответствии с быстро меняющимися социально-экономическими и эстетическими потребностями социума.

Площадь - наиболее показательное место любого города. В её архитектуре, как правило, отражается история города, периоды разрушения и созидания. Чем более заметное место занимает площадь в композиционной структуре города, чем 
больше на ней как на смысловом ядре размещается знаковых, сакральных сооружений, чем большее количество концепций и проектов её преобразования накапливается за многовековую историю существования, тем значительнее роль площади. Роль не только в истории города, но и государства, в его эволюции, социально-экономическом и политическом развитии общества. Площадь - лаборатория новых градостроительных идей, полигон воплощения креативных концепций зодчих, витрина результатов инициатив исполнительной власти.

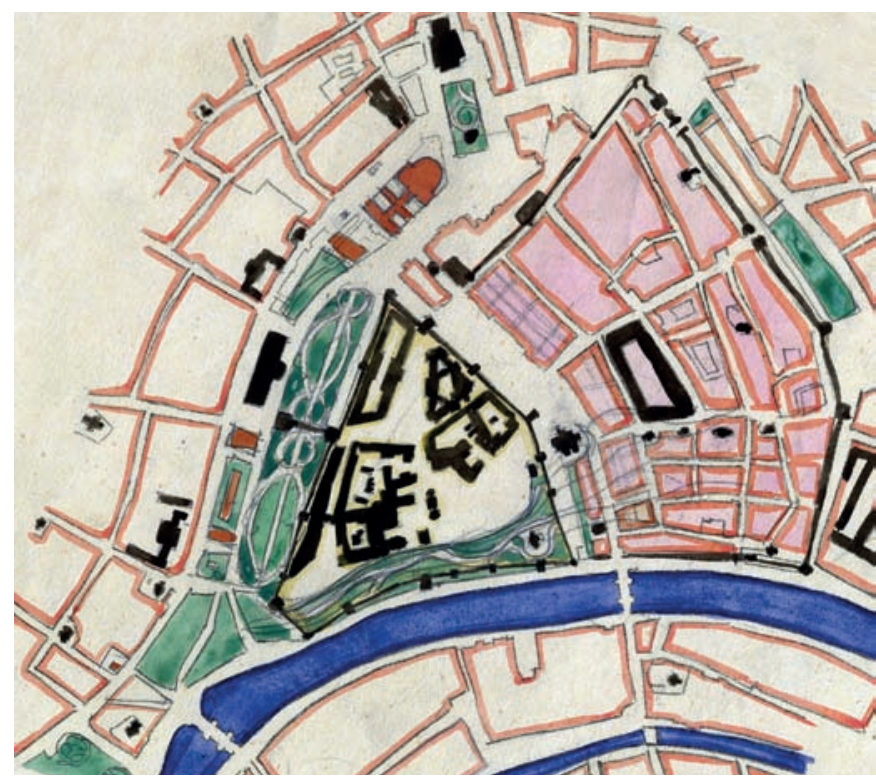

Рис. 1. 1922 год. Северо-западная часть центрального кольца площадей в эскизах к проектному плану «Новой Москвы» А.В. Щусева. На Охотнорядской площади размещён Дворец труда (источник: из коллекции А.М. Щусева)

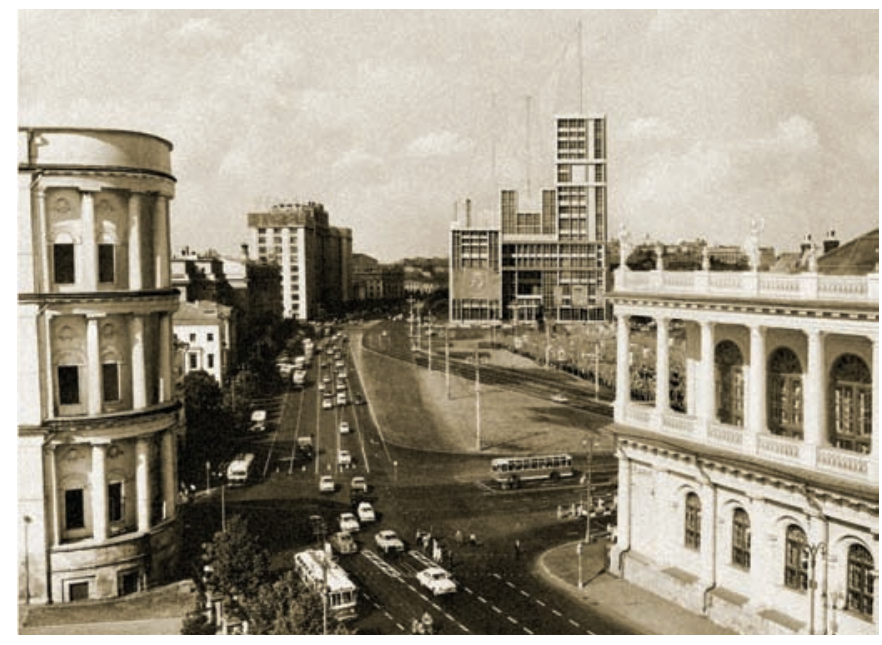

Рис. 2. Виртуальная реконструкция конкурсного проекта Дворца труда А.А., В.А. и Л.А. Весниных на Манежной площади (1922). Здания Манежа и Университета надстроены по проектам И.В. Жолтовского (1948). Памятник А.М. Горькому, скульпторы В.И. Мухина, И.Д. Шадр, архитектор 3.М. Розенфельд (1939). Реконструкция: архитекторы С.Б. Ткаченко, Н.К. Фидря, художник М.Б. Лепина (2019)
Городские площади определяют «...каркас, архитектурные и семантические особенности городского пространства. Именно в архитектуре площади сосуществуют здания различных эпох, соединение которых иногда позволяет достичь уникальной целостности и гармоничности пространства или, наоборот, проявить все композиционные противоречия, накопившиеся в городской структуре» [1, с. 224].

Существует множество теоретико-искусствоведческих подходов к раскрытию тематики аналогичных исследований, находящихся на стыке политики, градостроительства и архитектуры. При этом следует подчеркнуть, что перемещение границ исследований в сферу прикладных данных на основе известных и ранее не публиковавшихся проектных материалов может способствовать углублению и конкретизации понимания объекта исследования - роли нереализованных концепций в развитии города.

Процесс эволюции планировочной структуры центрального ядра Москвы, основанный на принципах преемственности, описан в трудах Ю.П. Бочарова, Н.Н. Броновицкой, Е.И. Кириченко, Ю.Л. Косенковой, М.В. Нащокиной, С.0. Хан-Магомедова и др.

Особое внимание формированию нового центра советской Москвы в 1920-1930-х годы уделено в работах В.Э. Хазановой и Ю.Д. Старостенко, подробно исследовавших и оценивших значение градостроительного воплощения программы увековечения памяти В.И. Ленина - проектам Аллеи Ильича.

Западная часть Кремлёвского полукольца, начинающаяся от Лубянской площади и заканчивающаяся у Москвы-реки, на протяжении веков предназначалась для размещения административно-культурного и торгового центра Москвы. В XX веке, после смерти в 1924 году В.И. Ленина, появилась принципиально иная градостроительная и архитектурномонументальная программа, впервые сформулированная в статье Л.Б. Красина «Архитектурное увековечение Ленина» [2]. В 1920-1950-х годах программа имела практическую направленность, в 1960-2000-х - рамочную.

Этой программе предшествовали другие документы. 20 декабря 1918 года на заседании Коллегии Отдела градоустройства Управления городского и сельского строительства BCHХ были заслушаны доклады Московской архитектурной мастерской о перепланировке и расширении Москвы (рис. 1). Одним из замечаний стало отсутствие в эскизах и картограммах правительственного центра: «Не принята во внимание Москва как государственный центр» [3, с. 37]. Впоследствии в проектном плане «Новой Москвы» административно-политический центр был размещён на Ходынском поле [4], однако органы советской власти сгруппировались в кварталах вокруг Кремля, что подтвердило мнение консультанта Коллегии Г.Д. Дубелира: «При планировке центра города желательно предусмотреть возможность постройки рядом с Кремлём <...> нового государственного административного центра» [3, с. 37].

Конкурс на проект Дворца труда (1922-1923) подтвердил намерения советской власти сгруппировать свои структуры управления около Кремля (рис. 2). 
Градостроительное и архитектурно-художественное содержание Кремлёвского полукольца как центрального ядра столицы СССР должно было соответствовать трём основным аспектам градостроительства: сакральному, государственному и утилитарному [5, с. 12].

При исследовании упомянутых выше аспектов в качестве временно́й шкалы применена периодизация московского градостроительства, основанная на ретроспективной оценке формирования планировочной структуры города в увязке с социально-экономическими и политическими факторами влияния [6, с. 345-348.]. Границы периодов и этапов не являются фиксированными датами, поэтому события процесса формирования Аллеи Ильича, выходящие за обозначенные периодизацией годы, группировались по смысловому значению.

Период первого социального эксперимента (19171935): революционно-романтический этап (1917-1928)

Концепция Аллеи Ильича - западной части Кремлёвского полукольца, появилась после смерти в 1924 году В.И. Ленина - как элемент программы увековечения памяти вождя. Комиссию по увековечению возглавлял Л.Б. Красин. Им была составлена градостроительная и архитектурно-монументальная программа [2], основными пунктами которой стали:

- возведение на Красной площади архитектурного сооружения - постоянной полуподземной гробницы, не являющейся памятником вождю;

- придание гробнице формы народной трибуны с надписью: «Ленин»;

- постановка в Москве памятников В.И. Ленину в нескольких местах: скульптурный памятник из бронзы установить в Кремле на месте памятника Александру II, второй - на сквере или авеню «25 октября» (рис. 3), большой памятник-музей соорудить на Воробьёвых горах;

- устройство сквера или авеню «25 октября» на месте снесённых кварталов напротив Университета, Румянцевского музея и музея изящных искусств;

- продолжение сквера вдоль левого берега реки Москвы в виде широчайшего проспекта имени Ленина, идущего к Воробьёвым горам;

- соединение Москвы с Воробьёвыми горами, переименовываемыми в «Горы Ленина», пересекающим реку Москву мостом имени Ленина.

После опубликования программы увековечения памяти В.И. Ленина выпускник ВХУТЕМАСа, член АСНОВА, архитектор-рационалист В.С. Балихин подготовил своё предложение: «...лучший памятник Ленину - Дом его имени, который в то же время будет и памятником образования Союза ССР и памятником Коминтерну» [7, с. 144]. Дом имени Ленина должен быть поставлен на месте Храма Христа Спасителя. В.С. Балихин не ограничился призывом к «предрешённому» сносу Храма Христа Спасителя, предложив своё видение перестройки центра Москвы. На месте Верхних торговых рядов на Красной площади должен быть построен Музей Революции,

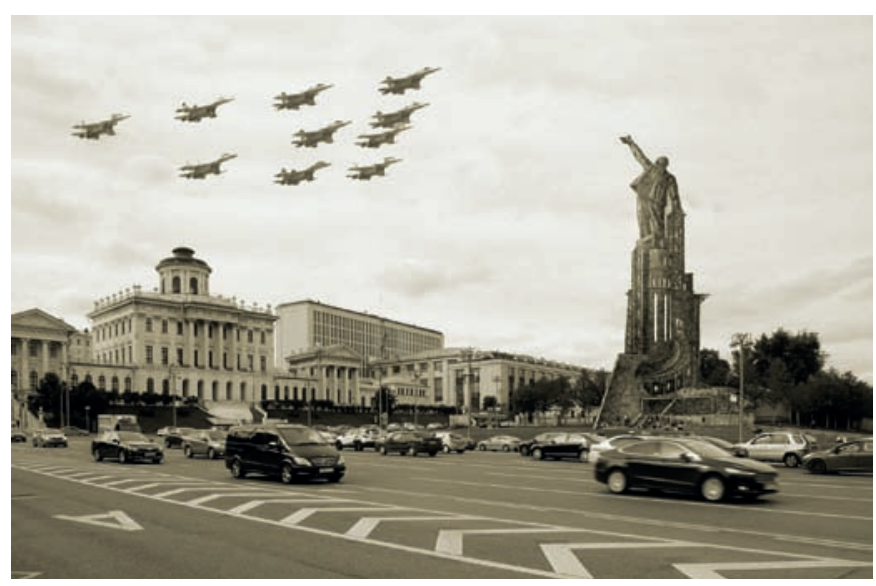

Рис. 3. Виртуальная реконструкция установки памятника В.И. Ленину на Аллее Ильича по программеувековечения памяти вождя (Л.Б. Красин, 1924). Памятник по эскизу В.А. Щуко (1924). Реконструкция: архитектор С.Б. Ткаченко, художник М.Б. Лепина (2020)

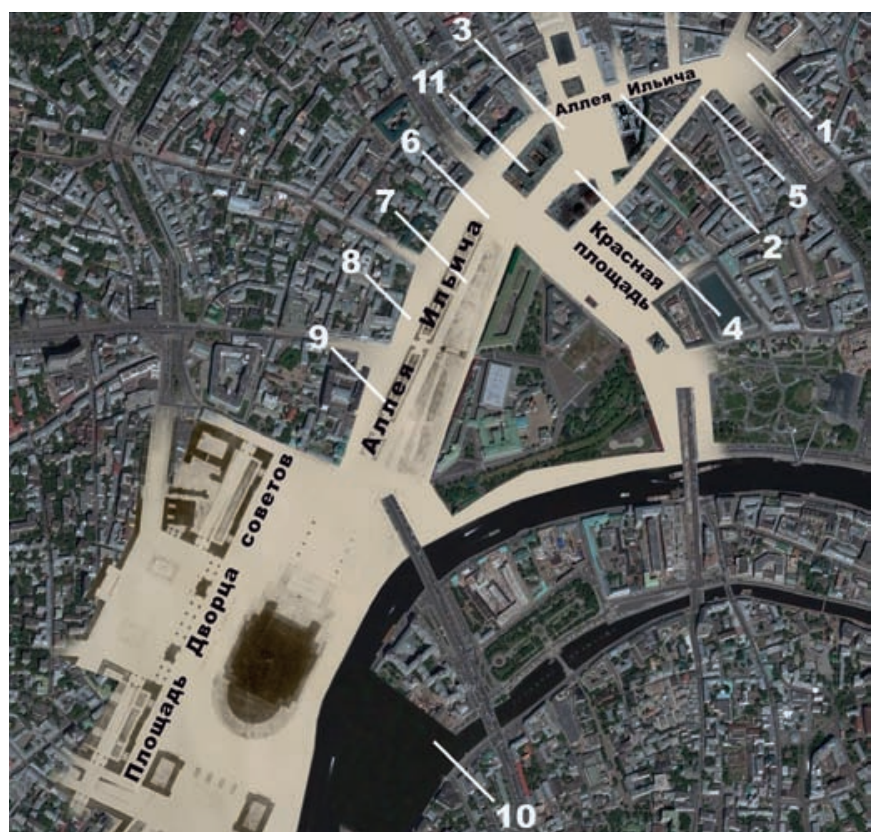

Рuс. 4. Схема Аллеи Ильича: 1 - Лубянская площадь (1926-1990 - площадь Дзержинского); 2 - Театральный проезд [1961-1990 - проспект Маркса. Проектные топонимы: авеню 25 Октября, проспект имени Ленина, Аллея Ильича, проспект Ильича (1924), Центральный проспект (1936), проспект Сталина (1949)]; 3 - Театральная площадь (1919-1990 -площадь Свердлова); 4площадь Револющии (с 1917); 5 - Никольская улица (1932-1990 - улица 25 Октября); 6 - Манежная площадь [1967-1990 - площадь 50-летия Октября. Проектный топоним: площадь Сталина (1949)]; 7 - проектный топоним: аллея Пятилетки (1931); 8 - Моховая улица [1961-1990 - проспект Маркса. Проектные топонимы: авеню 25 Октября, проспект имени Ленина, Аллея Ильича, проспект Ильчча (1924), Центральный проспект (1936), проспект Сталина (1949)]; 9-проектный топоним: сквер Ленина (1932), Центральные бульвары (1958); 10 - проектное расширение акватории Москвы-реки перед Дворцом советов (1940-1956); 11 - проектный топоним: площадь Федерации (2005) 
ГРАДОСТРОИТЕЛЬСТВО

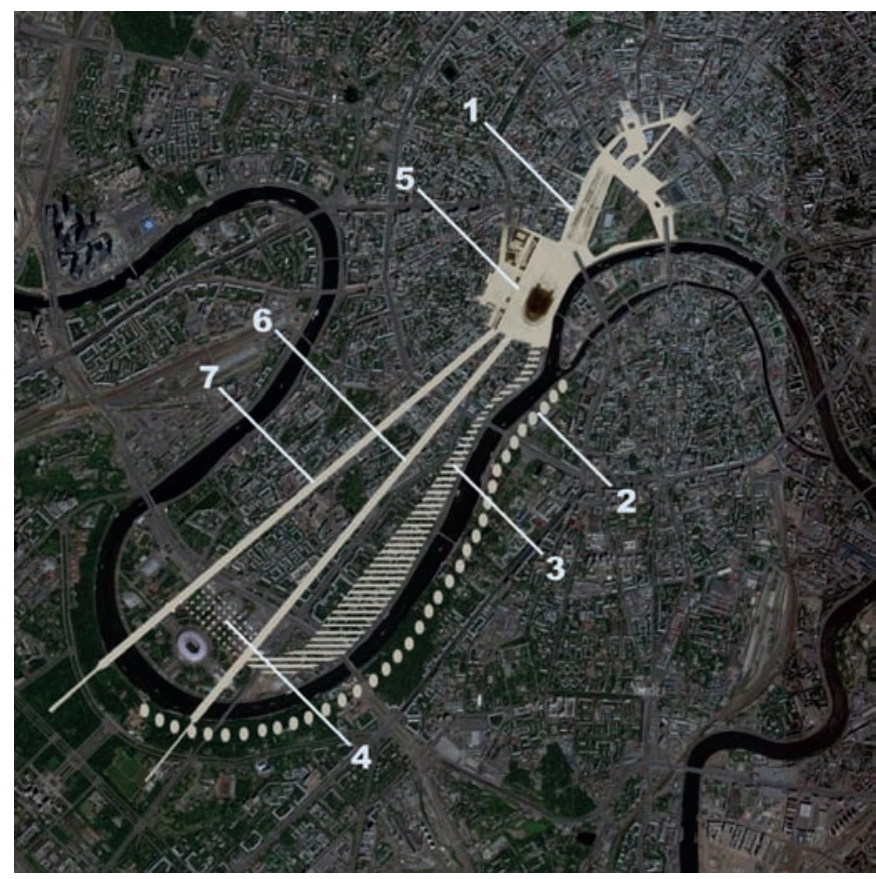

Рuc. 5. Схема Аллеи Ильича и проспекта Дворца советов: 1 - проектные топонимы: Аллея Ильича, Кремлевское полукольцо; 2 - проектный топоним: Аллея Ильича (1920-е); 3 - проектные топонимы: проспект имени Ленина (1924), Ленинский проспект (1924), Аллея Ильича (1931), аллея Ленина (1933); 4-проектный топоним: Поле массовых действ (1931); 5 - проектный топоним: площадь Дворца советов (1931-1956); 6 - проектные топонимы: Новый проспект (1935), проспект Дворца советов (1935), Сталинский проспект (1953); 7 - проектный топоним: проспект Дворца советов (1935)

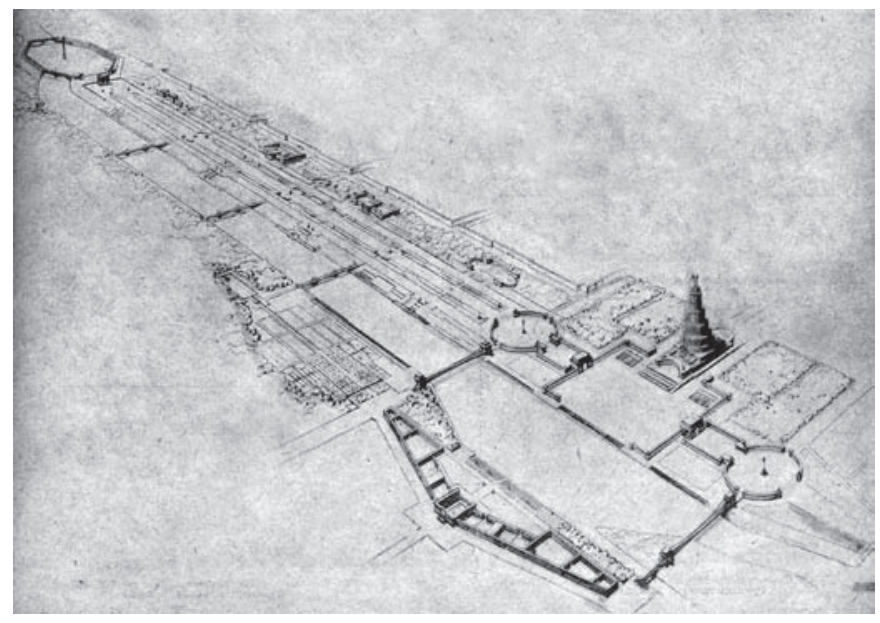

Рис. 6. Дипломная работа студента факультета жилищнообщественных сооружений Московского архитектурного института Чижикова «Аллея Ильича». Руководитель проф. А.П. Иваницкий (источник: Дипломные работы факультета Жилищно-общественных сооружений Архитектурного института // Архитектурная газета. - 1936, приложение к № 63)
Кремлёвское полукольцо и Китай-город трактовались как административный центр СССР и Москвы. «Ленинский проспект как “непрерывный цветущий парк” должен был раскинуться от Дворца Труда между Кремлём и Моховой-Волхонкой до памятника Ленину и “дальше, по набережной, до Сельскохозяйственной выставки и Ленинских гор"» [7, с. 144-145].

Предложение В.С. Балихина находило отклики в столичной градостроительной политике вплоть до 1970-х годов. В «Проекте детальной планировки центра Москвы в пределах Садового кольца» 1972 года выделялась зона идеологическивоспитательных и культурно-просветительных учреждений, в состав которой входил музейно-мемориальный комплекс, включавший музей В.И. Ленина, музей Революции, Кремль и Красную площадь [8].

Программа увековечения памяти стала реализовываться: конкурс I степени на составление проекта постоянного мавзолея В.И. Ленина был объявлен в январе 1925 года, Воробьёвы горы были переименованы в Ленинские. «Аллея Ильича» начала фигурировать в профессиональной прессе и архитектурных проектах (рис. 4, 5).

Сначала Аллея Ильича попала в программы студенческого проектирования ВХУТЕМАСа. Известно, что А.А. Веснин, давая темы дипломных работ своим студентам из ВХУТЕМАСа, практиковал проработку основных направлений текущей и перспективной градостроительной политики. Так было с работами И.И. Леонидова - студента группы Весниных архитектурного факультета: «Типография газеты “Известия"» (рук. А.А. Веснин, 1926), «Институт библиотековедения имени В.И. Ленина на Ленинских горах» (рук. А.А. Веснин, 1927) [9].

В связи с этим заслуживают внимания темы студенческих проектов, связанные с Аллеей Ильича. Так, например, в 1927 году выставка контрольных работ Архитектурного факультета ВХУТЕМАС'a была посвящена проектам нового здания Высшей художественной школы на территории бывшей сельскохозяйственной выставки на Крымском валу. В описании «художественного городка» говорилось: «Вдоль всего участка, по берегу Москвы-реки, проходит “аллея Ильича", соединяющая центр города с “спортивным городом" на Ленинских горах» [10].

Студенты факультета жилищно-общественных сооружений Московского архитектурного института до конца 1930-х годов брали темой дипломного проекта «Аллею Ильича». Среди лучших в 1936 году был проект дипломанта Чижикова (рис. 6). Руководил дипломантом профессор А.П. Иваницкий. В дипломной работе главный вход во Дворец Советов был развернут в сторону площади, спускавшейся к Москве-реке. От Триумфальной арки, стоявшей на площади, параллельно набережной Москвы-реки на юго-запад шла Аллея Ильича. Четырёхчастная компоновка протяжённого пространства бульвара и развитой набережной получалась благодаря мостам через спрямлённое русло реки. Продольную ось Аллеи Ильича, разбитую мостами на равные квадраты, образовывала эспланада от арки до арки. Между эспланадой и квартальной застройкой в пышной зелени 
располагались общественные объекты. Места пересечения поперечных проходов - продолжений мостов, и эспланады отмечены квадратными площадями с фонтанами в центре. Начинаясь от прямоугольной площади Дворца Советов, Аллея Ильича завершалась водным пространством, обрамлённым восьмигранником трибун. Территориальные границы Аллеи Ильича практически совпадали с конкурсными проектами 1931 года на планировку ЦПКи0.

Достаточно показательно, что тема дипломных работ «Аллея Ильича» была актуальна наряду с темой «Дворец молодёжи». В случае пересмотра градостроительной политики высшими эшелонами власти такая тема не смогла бы фигурировать в учебно-воспитательном процессе ведущего архитектурного вуза страны.

Подводя итоги этапа 1917-1928 годов, можно отметить, что сакральное, сливаясь с государственным, возникало в концепциях, рождённых в атмосфере социального оптимизма, но не имевших реальной базы для реализации и не опиравшихся на профессиональные ресурсы. На революционно-романтическом этапе в градостроительстве укрепилось внедрение открытой символики, прямо связанной с «агитационными формами изобразительного и театрального искусства» [11, с. 279] - наследия послереволюционных лет. Именно для этого этапа характерно создание «торжественной праздничности пространства» [11, с. 280], заложенное в январе 1924 года программой Аллеи Ильича. Утилитарное практически отсутствовало, существуя лишь в масштабах НЭПа (1921-1928).

\section{Период первого социального эксперимента (1917-} 1935): поисковый этап (1928-1935)

Практически первый проект, в котором трасса Аллеи Ильича переведена с набережной на юго-западную планировочную ось города, выполнил Б.М. Иофан к первому туру конкурса на Дворец Советов СССР (рис. 7). В этом проекте Аллея Ильича приобрела иное качество: из зоны проведения массовых мероприятий она стала идеологическим вектором монументальной реконструкции исторического ядра Москвы.

В 1931 году для составления генерального плана дальнейшего развития Центрального парка культуры и отдыха, открывшегося в августе 1928 года, был проведён заказной конкурс. Заданием для приглашённых участников послужила программа строительства парка. Одна из общих задач парка была достаточно чётко сформулирована в проекте бригады АСИ (Архитектурно-строительного института): «...парк является местом, где заканчиваются все общегородские демонстрации, берущие начало на Красной площади и мимо Дворца советов по аллее Ильича попадающие в парк» [12]. В проекте АСИ Аллея Ильича, начинаясь у Крымского моста, отклонялась на запад, к Институту Маркса и Энгельса и далее - к Полю массовых действ с трибунами на 150000 человек (рис. 8 а).

В проекте И.У. Бронштейна (Сектор архитекторов социалистического строительства - (АСС) роль Аллеи Ильича

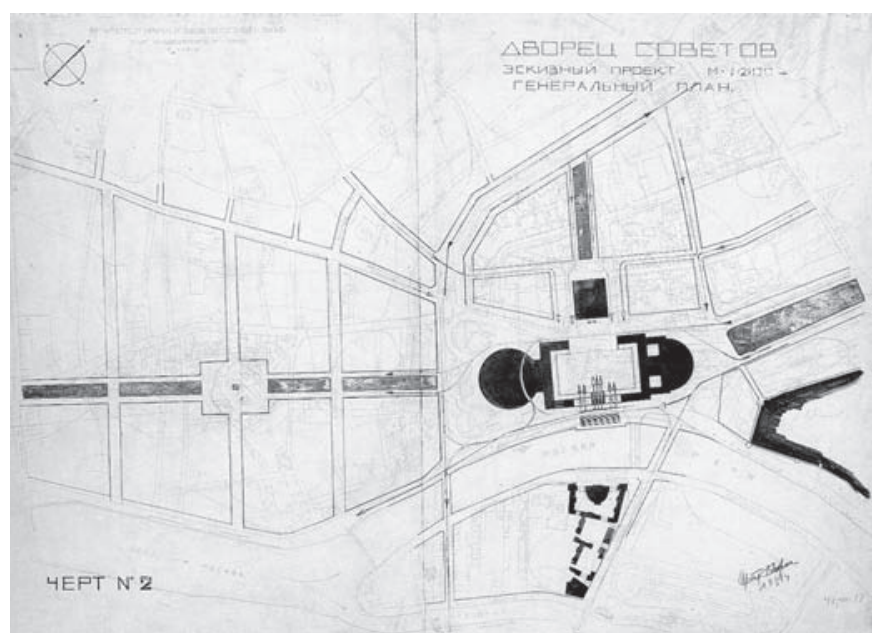

Puс. 7. 1931 год. Конкурсный эскизный проект Дворца Советов СССР. Предварительный тур конкурса, первый тур конкурса. Генеральный план. Арх. Б.М. Иофан. 1931 год (источник: [15, с. 107])

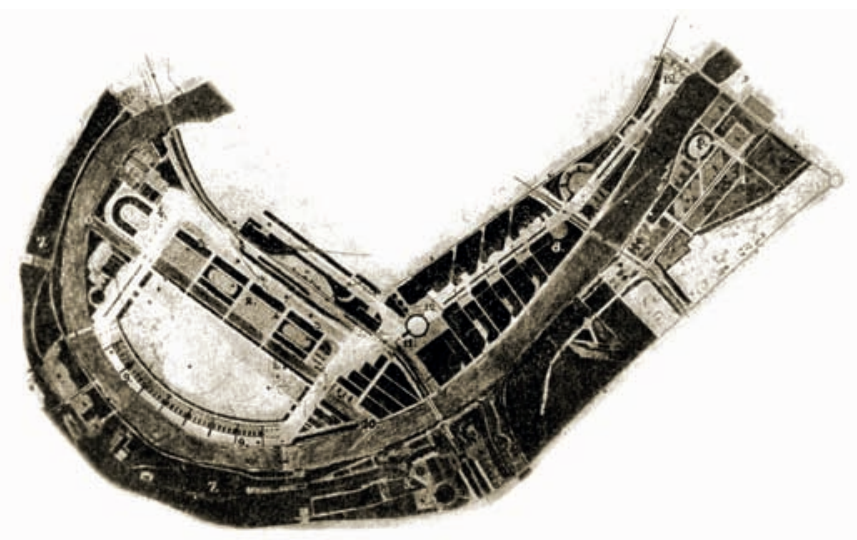

a)

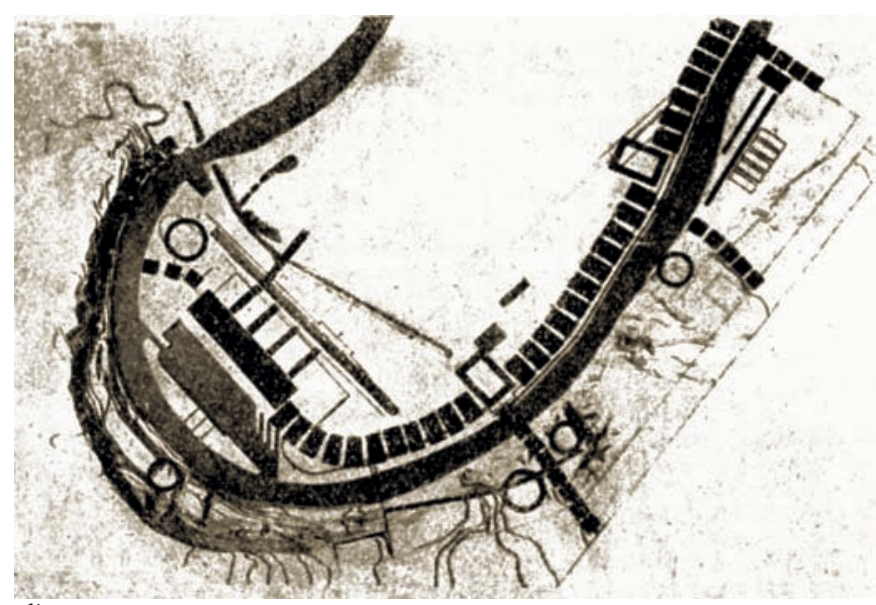

б)

Рис. 8. 1932. Конкурс на составление генерального плана дальнейшего развития Центрального парка культуры и отдыха: а) проект бригады АСИ (арх. А.В. Натальченко, П.П. Ревякин, К.Я. Рогов); б) проект бригады ЦПКиО (арх. Л.С. Залесская, И.П. Кычаков, М.И. Прохорова). Схема движения колонн демонстрантов (источник: [12]) 
выполнял канал с набережными, перспектива которого заканчивалась на правом берегу Москвы-реки Домом обороны. В проекте бригады АРУ (Объединение архитекторовурбанистов, В.П. Калмыков, В.И. Фидман) Аллея Ильича вела к центру массовой политической работы - Полю массовых действий в Лужниках. Бригада АСНОВА (Ассоциация новых архитекторов, Т.Н. Варенцов, С.А. Гельфельд, А.И. Репкин) соединила отрезками Аллеи Ильича выставочный и физкультурный секторы, которая после этого петлёй обходила Поле массовых действий. В проекте бригады В0ПРА (Всероссийское общество пролетарских архитекторов, П.И. Гольденберг, В.И. Долганов) представлена гипотеза о создании двух поясов парков вокруг Москвы. В реконструкции центра города авторы предложили отказаться от кольцевой системы и перейти к радиусам: «На радиусе Дворец Советов - Ленинские горы центром становилось направление Аллея Ильича - ЦПКи0, а стержнем его - Москварека» [11, с. 285]. Трёхуровневая Аллея Ильича связывала центр столицы с Лужниками.

Более погруженная в градостроительные планы перестройки столицы бригада архитекторов ЦПКи0 провела Аллею Ильича, связывающую «первый парк в СССР» с центром города и Дворцом советов, по набережной Москвы-реки, выводя её в Лужники (рис. 8 б).

(После неудачи с возведением Международного Красного стадиона на оползневом массиве смещающихся грунтов склона Воробьёвых гор, местом его строительства по проектам 1924-1925 годов должны были стать Лужники).

Ни в одном конкурсном проекте ЦПКи0 (даже у бригады В0ПРА - с усилением роли радиусов) Аллея Ильича не приобрела общегородского планировочного значения.

К 1931 году по заданию Планово-земельного отдела МКХ Исполкома Моссовета под руководством В.Н. Семёнова была выполнена эскизная схема перепланировки Москвы. В схеме указывался столичный планировочный центр: «...площади Охотнорядская, Свердловская, Дзержинская, прорезанные городской сверхмагистралью - Аллея Ильича - центр - Каланчёвка». Предполагалось, что: «в дальнейшем развитие и рассасывание городского центра пойдёт по линиям городского и ж.-д. диаметров. По магистрали Аллея Ильича - центр - Каланчёвка осядут хозяйственно-управленческие учреждения (Мясницкая ул.) и культурно-просветительские и общественные учреждения (Аллея Ильича, Ленинские горы)» [13].

В 1932 году не только в профессиональной прессе, но и в выступлениях лидеров партии, а также в директивных документах ВКП(б) началась кампания по разъяснению положений перепланировки Москвы, сохранению радиально-кольцевой системы, юго-западному вектору роста, функциональному и архитектурно-пластическому развитию столичного центра: «...в Москве нет центральной магистрали, нет проспекта, который бы резко выделялся, служил ведущим началом. <..> ...превратить проезд от площади
Дзержинского до Дворца советов в прекраснейший центральный проспект города, который должен стать гордостью Москвы» [14].

Тогда же, в 1932 году, проводился международный конкурс проектов планировки Москвы. Ведущие архитекторы вплотную работали над этой темой с конца 1920-х годов, участвовали в дискуссии о расселении. К 1930 году позиции сформировались: Н.А. Ладовский обнародовал «Город-ракету», ориентированный на развитие столицы на северо-запад, Ле Корбюзье подал на рассмотрение проект «Лучезарный город». На вопросы анкеты МОКХ (Отдел Московского коммунального хозяйства Моссовета) к конкурсу на перепланировку Москвы в 1930 году отвечали Э. Май, В.В. Бабуров (ВОПРА). Участники конкурса были знакомы с позицией власти по поводу планов планировки Москвы, однако, уверенные в своей правоте, отстаивали собственные стратегии развития столицы.

В некоторых проектах произошли совпадения с официальными планами. Так, например, бригада ВоПРА (В.В. Бабуров, А.А. Карпов, И.П. Кычаков и др.) прокладывала центральную магистраль, по которой развивался общегородской центр, по юго-западной оси - от Дворца советов к Лужникам. Зону центра ограничивала Аллея Ильича, проходившая по Хамовнической набережной, и магистраль в центре Лужнецкой излучины Москвы-реки: «Старый “исторический и революционный центр" - Кремль и Красная площадь - сохранялся и развивался по направлению диаметра: Аллея Ильича - Новомясницкий проспект» [11, с. 297] (рис. 9, 10).

В это же время происходит перелом во всей структуре советской архитектуры. Институциональные изменения - создание в 1932 году Союза советских архитекторов и ликвидация формально независимых творческих объединений - вызванные усилением роли и влияния ВКП(б) на все процессы, происходившие в государстве, постепенно вывели градостроительство на первый план, оставив вопросы архитектуры в подчинении у градостроительной политики. Ансамблевый подход к реконструкции исторических городов обрёл поддержку в лице лидеров советской власти. И хотя любые градостроительные решения инициируются и реализуются властными структурами - партийной и исполнительной властью, градостроительство «...в условиях диктаторских режимов характеризуется особой формой примата политики» [15, с. 281].

Перепланировкой центра Москвы в 1930-е годы занимались почти все выдающиеся зодчие того времени. Среди них были А.В. Щусев и И.В. Жолтовский. Отсутствие творческого единоначалия в проектировании центра вносило разнобой в проектные решения, предлагавшиеся партийной и исполнительной властью для принятия управленческих решений. В 1932 году начало работать Архитектурно-планировочное управление (АПУ), которое, кроме глобальной задачи - генеральной перепланировки города, должно было решать: «...сугубо практические задачи оперативного характера», 


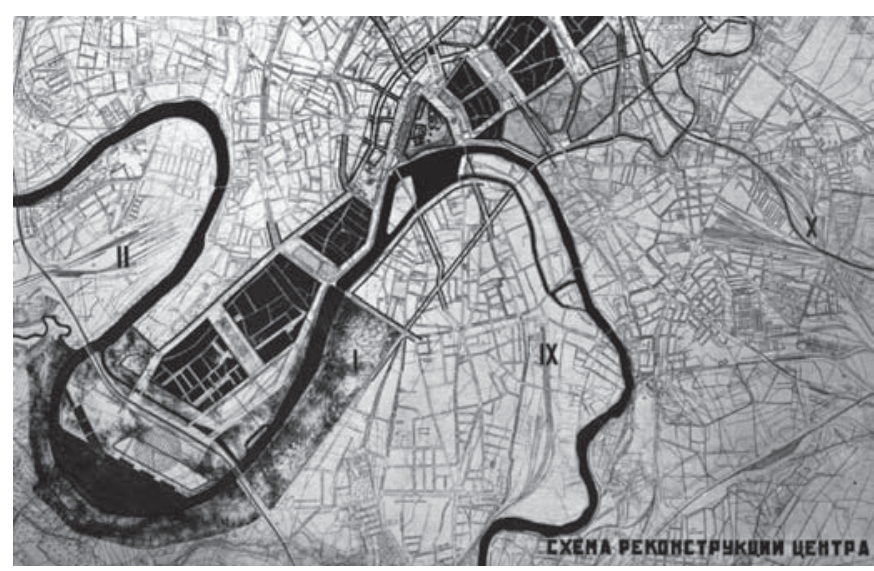

Рис. 9. 1932 год. Конкурсный проект планировки Москвы. Фрагмент Схемы реконструкции центра (бригада ВОПРА)

и одна из них: «...текущая планировка города, связанная с его застройкой в настоящий момент» [16]. Работа АПУ в этот период не была продуктивной. Не помогло и назначение магистральных архитекторов - хозяев застройки, отвечавших за неё: центр попадал в зону ответственности нескольких магистральных архитекторов.

А.В. Щусев проектировал площадь Охотного ряда как один из административных центров столицы. В 1934 году он писал: «...0хотнорядская площадь (пора уже подумать о переименовании этой центральной площади) явится началом будущей аллеи Ильича, ведущей к Дворцу советов» [17]. В проекте магистрали «Ленинградское шоссе - Автозавод им. Сталина» он давал планировку и перспективы площади Охотного ряда (рис. 11).

И.В. Жолтовский тоже занимался проектом реконструкции Кремлёвского полукольца. В статье о статике площадей и динамике улиц И.В. Жолтовский пишет и об Аллее Ильича: «Новый центр Москвы в ближайшие годы, вероятно, образует мощные сооружения типа Дворца советов, Дворца Наркомтяжпрома, сооружения вдоль аллеи Ильича» [18].

Перестройка Третьяковского проезда была задумана И.В. Жолтовским в 1932 году: верхнюю часть ворот, «сооружённую в дурном псевдо-русском стиле», предполагалось разобрать, а сами ворота «переработать в строгом стиле классической архитектуры». С учетом перестройки и надстройки здания бывшего MKX на противоположной стороне Театрального проезда (С.Е. Чернышев, 1934) эти мероприятия должны придать Театральному проезду «монументальный вид, и архитектурный разнобой будет ликвидирован» [19].

Площадь Свердлова также подлежала коренной перестройке. За основу брался проект 0.И. Бове 1821 года. B.Н. Семёнов писал, что площадь Свердлова: «...была задумана как единый архитектурный ансамбль, подчинённый и по стилю и по массам Большому театру и свободному пространству площади. <...> Очевидно, надо было вернуться

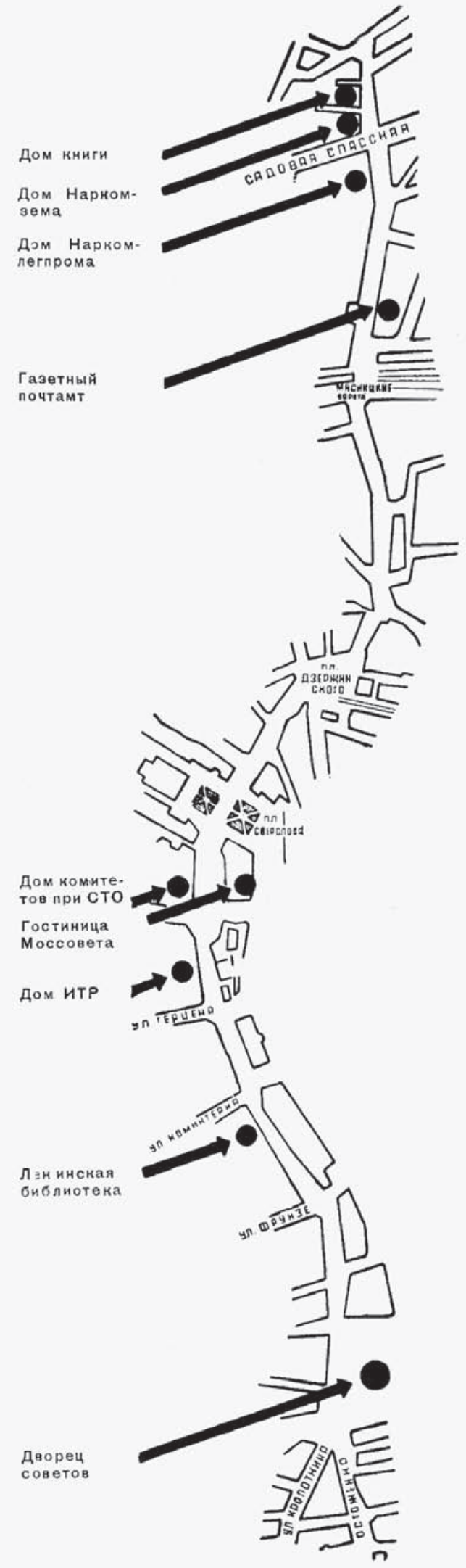

Рис. 10. 1933 год. Схема магистрали «Орликов переулок Дворец советов» $K$ югу от площади Дзержинского - Аллея Ильича (источник: Архитектура в борьбе за качество // Архитектура СССР. - 1933. - № 2. - С. 2) 
к первоначальному замыслу архитектора» [20]. Добиться восстановления архитектурного ансамбля площади и достижения композиционного единства предлагалось при

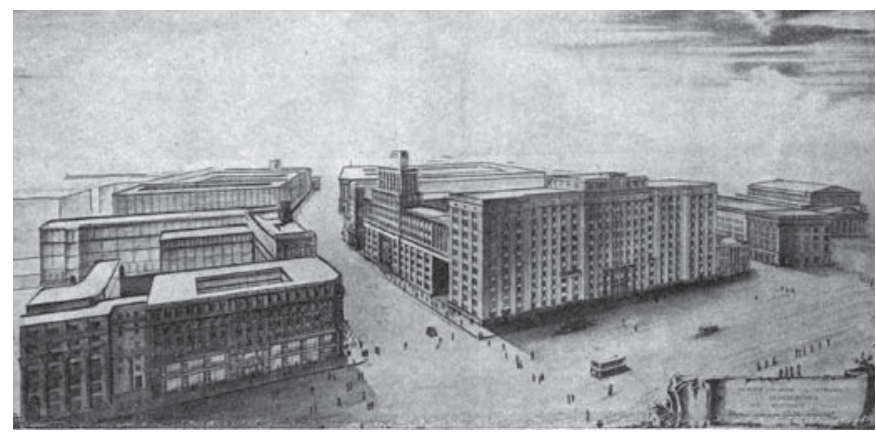

a)

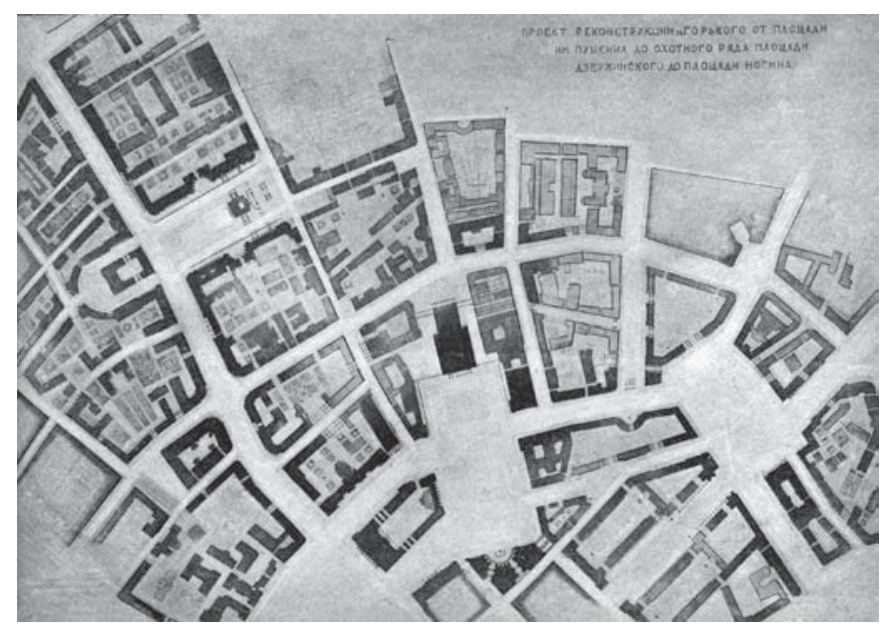

б)

Рис. 11. 1936 год. Магистраль «Ленинградское шоссе Автозавод им. Сталина». Проект реконструкции улицы Горького от площади им. Пушкина до Охотного ряда, площади Дзержинского, площади Ногина. Архитектурно-планировочная мастерская №1 Моссовета. Архитекторы А.В. Щусев, А.В. Снигарёв: а) перспектива от Охотного ряда; б) генеральный план (источник: Магистраль «Ленинградское шоссе - Автозавод им. Сталина» // Архитектурная газета. - 1936. - Приложение к № 43

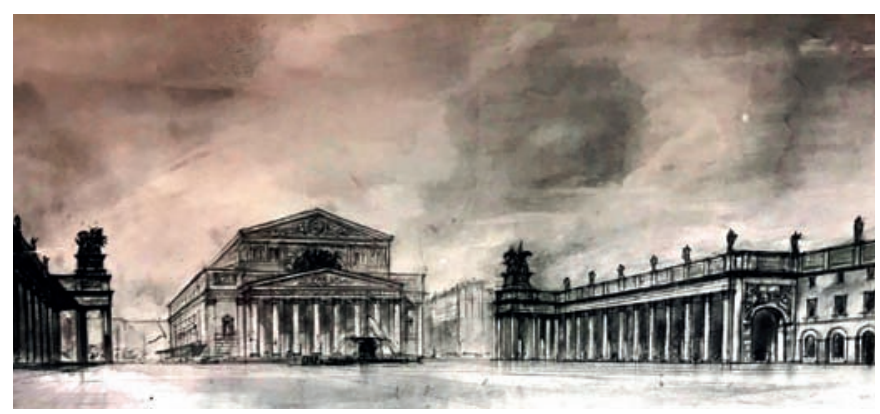

Рис. 12. 1934 год. Проект реконструкции площади Свердлова (вариант). Архитектор И.В. Жолтовский (источник: ГНИМА. Колл. VIII. Нег. 31578) помощи сооружения колоннады на всю высоту застройки, по периметру украшенной скульптурными группами. Малый театр надстраивался в средней части (рис. 12).

Фасад гостиницы «Метрополь» подлежал перестройке «в духе, соответствующем классическому характеру площади», причём «...безвкусные лепные детали и часть не имеющей художественной ценности майолики будут сбиты» [19]. (После превращения «Метрополя» во Второй Дом Советов в 1918 году майоликовая надпись - цитата из Ф. Ницше, была заменена на цитату из В.И. Ленина. Остальные «не имеющие художественной ценности» майоликовые панно были выполнены по картонам М.А. Врубеля, А.Я. Головина. С.В. Чехонина.) В Китайгородской стене сооружались монументальные входы и въезды, от них пробивалась магистраль в Замоскворечье, к будущему диаметру Север-Юг.

От ликвидируемого Охотного ряда начинался проспект Ленина, идущий на юго-запад, через площадь Дворца советов до Ленинских гор. На месте сноса кварталов напротив Университета разбивался сквер проспекта Ленина. Здание Манежа реконструировалось под кинотеатр и большой зал собраний. Бульвары и скверы на расчищаемых от застройки участках вдоль Александровского сада и Моховой улицы продолжали стратегию «города-сада», предложенную проектным планом «Новой Москвы» в 1918-1923 годы.

Проект Дворца советов был утверждён и принят к строительству в 1933-1934 годы. Этот факт повлиял на советскую градостроительную теорию и практику: «примат пространства города в проектах перепланирования сменялся главенством объёмных композиций» [11, с. 303], и первая из них - Дворец советов.

К 1934 году, после очередной перестройки советского градостроительства в сторону «освоения исторического наследия», переход к проектированию ансамблей стал проявляться не только в проектах, но и в реальной застройке главных магистралей столицы - улицы Горького, набережных. Скорость проектирования приводила к нарушению последовательности. Как правило, сначала появлялись проекты зданий или локальные ансамбли: «...архитекторы, проектировавшие отдельные здания на конкретных улицах, не брали в расчёт общий замысел её застройки, поскольку его могло ещё просто не существовать» [21].

Принцип «Время, вперёд!» обострял борьбу концепций и опережающего их строительства, усложнял реализацию грандиозных замыслов преобразования столицы. Проект Аллеи Ильича ещё не был принят, а по его трассе уже проектировались и строились несколько зданий: гостиница Моссовета (А.В. Щусев, Л.И. Савельев, 0.А. Стапран, 19321937), Библиотека им. Ленина (В.А. Щуко, В.Г. Гельфрейх, 1928-1941), Дом СТО (А.Я. Лангман, 1933-1934), жилой дом специалистов ИТР на Моховой (И.В. Жолтовский, 1932-1934). Планировочные решения должны были подстраиваться под постоянно менявшееся существующее положение (рис. 13). 
В первой половине 1930-х годов архитектурные фантазии 1920-х сменились архитектурным прогнозированием: поэтапно развивавшимися, но почти не реализованными концепциями и проектами. «Градостроительные замыслы рубежа 30-х годов были схематизированными мечтами или романтизированными схемами. <...> Схемы ещё не превратились в проекты». Градостроительные приёмы были созвучны «волевым ритмам маршей» [11, с. 75]. В этом выражался сакральный аспект градостроительства поискового этапа. Государственное начало прочно входило в развитие города через укрепление централизованного планирования в градостроительной и земельно-имущественной сфере. Только при этих условиях было возможно в 1932-1934 годы снести Китайгородскую стену, расширить Театральный проезд и сломать кварталы по будущей трассе Аллеи Ильича.

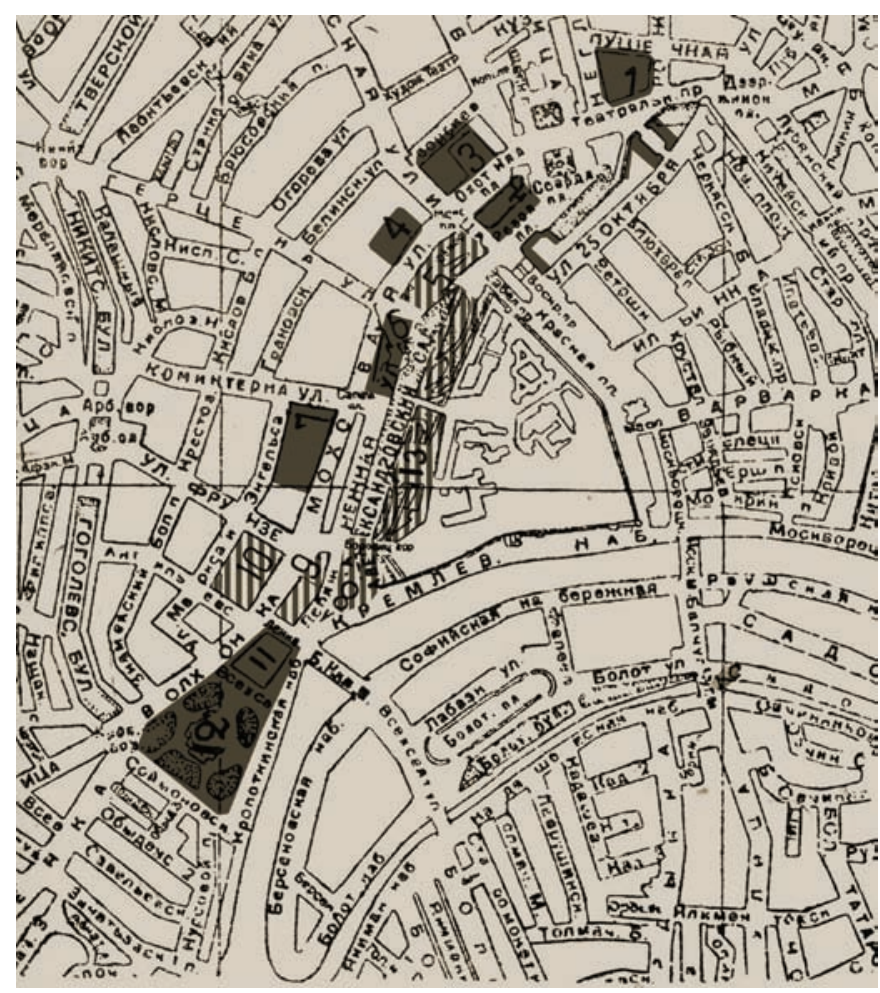

Рис. 13. 1932 год. Район пробивки Аллеи Ильича на Кремлёвском полукольце от площади Дзержинского до участка строительства Дворца советов. Отмечены: надстройка дома MКX по Театральному пр., 3 (С.Е. Чернышев, 1934), реконструкция фасадов гостиницы «Метрополь», реконструкция фасадов и надстройка Третьяковского проезда, гостиница Моссовета, гостиница «Интурист» (на этом участке построен Дом (Т0), перестраиваемый под кинозал и большой зал собраний Манеж, Библиотека им. В.И. Ленина, участок Дворца советов. Штриховкой отмечены предназначенные к сносу кварталы и подсыпаемый Александровский сад (источник: Соболев Центральная магистраль столицы преобразуется // Строительство Москвы. - 1932. - № 8-9. - С. 23. Обработка автора)

\section{Лuтература}

1. Никулина, Е.Г. Городская ткань: архитектура и время / Е.Г. Никулина; сост. И.В. Крымова. - М. : Моспроект-2, 2011. - 304 С.

2. Красин, Л.Б. Архитектурное увековечение Ленина / Л.Б. Красин // 0 памятнике Ленину / ред. Э. Голлербах.- Л. : ГИЗ, 1924. - С. 23-33.

3. Из истории советской архитектуры. 1917-1925 гг. Документы и материалы / ред. К.Н. Афанасьев, сост. В.Э. Хазанова. - М. : Издательство АН СССР, 1963. - 251 с.

4. Бочаров, Ю.П. Формирование столичных функций Москвы в планировочной структуре города с 1918 по 2018 год / Ю.П. Бочаров, С.Б. Ткаченко // Academia. Архитектура и строительство. - 2019. - № 3. - С. 58-69.

5. Кириченко, Е.И. Градостроительство России середины XIX - начала XX века / Е.И. Кириченко, М.В. Нащокина. - М. : Прогресс-Традиция, 2001. - 340 с.

6. Ткаченко, С.Б. Один век московского градостроительства : В 2 т. Книга первая. Москва советская / С.Б. Ткаченко. - М. : Прогресс-Традиция, 2019. - 376 с.

7. По: Старостенко, Ю.Д. Метаморфозы архитектурноградостроительной концепции развития центра (центрального ядра) Москвы в 1920-е -1930-е гг. : дис. ... канд. арх. : 18.00.01. - М., 2009. - 218 с.

8. Проект детальной планировки центра Москвы в пределах Садового кольца (основные положения). - М. : ГлавАПУ, 1974. - 56 с.

9. Гозак, А.П. Иван Леонидов. (Avant Garde) / А.П. Гозак. - М. : Жираф, 2002. - 240 с.

10. Лавр. Вит. [Лавров, В.А.] 0 новом здании Высшей Художественной школы в Москве / В.А. Лавров // Строительство Москвы. - 1927. - № 4. - С. 8-10.

11. Хазанова, В.Э. Советская архитектура первой пятилетки В.Э. Хазанова. - М. : Наука, 1980. - 376 с.

12. Луни, Л.Б. Перспективы строительства Центрального парка культуры и отдыха /Л.Б. Лунц // Советская архитектура. - 1932. - № 1 (7). - С. 35-52.

13. Болдырев С. Москва. Вопросы перепланировки / С. Болдырев, П. Гольденберг, В. Долганов // Советская архитектура. - 1931. - № 4. - С. 32-37.

14. Булганин, Н.А. Строительство и реконструкция Москвы / Булганин Н.А. // Строительство Москвы. - 1932. - № 8-9. - С. 4-7.

15. Градостроительство в тени Сталина / сост. Х. Боденшатц, К. Пост. - Verlagshaus Braun / SCIO Media, 2015. - 416 с.

16. Крюков М.В. Что и как делает АПУ. Историческое для советской архитектуры совещание / М.В. Крюков // Строительство Москвы. - 1932. - № 10. - С. 4-5.

17. Щусев А.В. Площади Триумфальная, Охотнорядская, Дворца техники / А.В. Щусев // Архитектура СССР. - 1934. - № 2. - С. 14-16.

18. Жолтовский И.В. Площадь Свердлова / И.В. Жолтовский // Архитектура СССР. - 1934. - № 2. - С. 14.

19. Соболев [И.Н.] Центральная магистраль столицы преобразуется / И.Н. Соболев // Строительство Москвы. - 1932. - № 8-9. - С. 21-25. 
20. Семёнов, В.Н. Вопросы планировки / В.Н. Семёнов // Академия архитектуры. - 1935. - № 4. - С. 39-43.

21. Старостенко, Ю.Д. Проблема ансамбля в советском градостроительстве 1920-1930-х гг. в теории и на практике / Ю.Д. Старостенко // Советское градостроительство. 19171941. - М. : Прогресс-Традиция, 2018. - 820 с. - С. 327-366.

\section{References}

1. Nikulina E.G. Gorodskaya tkan': arkhitektura i vremya [Architectural perpetuation of Lenin] [Urban fabric: the architecture and time], sost. I.V. Krymova (comp.). Moscow, Mosproekt-2 Publ., 2011, 304 p.

2. Krasin L.B. Arkhitekturnoe uvekovechenie Lenina [Architectural perpetuation of Lenin]. In: 0 pamyatnike Leninu [On the monument to Lenin]. Leningrad, GIZ Publ., 1924, pp. 23-33.

3. Iz istorii sovetskoi arkhitektury. 1917-1925 gg. dokumenty i materialy [From the history of Soviet architecture. 1917-1925 documents and materials], K.N. Afanas'ev (ed.), V.E. Khazanova (comp.). Moscow, AN SSSR Publ., 1963, 251 p.

4. Bocharov Yu.P., Tkachenko S.B. Formirovanie stolichnykh funktsii Moskvy v planirovochnoi strukture goroda s 1918 po 2018 god [Formation of Moscow's capital functions in the city's planning structure from 1918 to 2018]. In: Academia. Arkhitektura i stroitel'stvo [Academia. Architecture and construction], 2019, no. 3, pp. 58-69 (In Russ., abstr.in Engl.).

5. Kirichenko E.I., Nashchokina M.V. Gradostroitel'stvo Rossii serediny XIX - nachala XX veka [Urban planning in Russia in the mid-XIX - early XX century]. Moscow, Progress-Traditsiya Publ., 2001, 340 p.

6. Tkachenko S.B. Odin vek moskovskogo gradostroitel'stva. V 2 t. Kniga pervaya. Moskva sovetskaya [A century of urban development of Moscow. In 2 vol. Book one. Moscow Soviet]. Moscow, Progress-Traditsiya Publ., 2019, 376 p.

7. According to: Starostenko Yu.D. Metamorfozy arkhitekturno-gradostroitel'noi kon-tseptsii razvitiya tsentra (tsentral'nogo yadra) Moskvy v 1920-e -1930-e gg. [Metamorphoses of the architectural and urban development concept of the center (Central core) Moscow in the 1920s -1930s.] : dis. ... kand. arkh. : 18.00.01. Moscow, 2009, 218 p.

8. Proekt detal'noi planirovki tsentra Moskvy v predelakh Sadovogo kol'tsa (osnovnye polozheniya) [Project of detailed planning of the center of Moscow within the Garden ring (main provisions)]. Moscow, GlavAPU Publ., 1974, 56 p.

9. Gozak A.P. Ivan Leonidov. (Avant Garde). Moscow, Zhiraf Publ., 2002, $240 \mathrm{p}$.
10. Lavrov V.A. 0 novom zdanii Vysshei Khudozhestvennoi shkoly v Moskve [About the new building of the Higher Art school in Moscow]. In: Stroitel'stvo Moskvy [Construction of Moscow], 1927, no. 4, pp. 8-10.

11. Khazanova V.E. Sovetskaya arkhitektura pervoi pyatiletki [Soviet architecture of the first five-year plan]. Moscow, Nauka Publ., 1980, 376 p.

12. Lunts L.B. Perspektivy stroitel'stva Tsentral'nogo parka kul'tury i otdykha [Prospects for the construction of the Central Park of Culture and Leisure]. In: Sovetskaya arkhitektura [Soviet architecture], 1932, no.1 (7), pp. 35-52.

13. Boldyrev S., Gol'denberg P., Dolganov V. Moskva. Voprosy pereplanirovki [Moscow. The issues of redevelopment]. In: Sovetskaya arkhitektura [Soviet architecture], 1931, no. 4, pp. 32-37.

14. Bulganin N.A. Stroitel'stvo i rekonstruktsiya Moskvy [Construction and reconstruction of Moscow]. In: Stroitel'stvo Moskvy [Construction of Moscow], 1932, no. 8-9, pp. 4-7.

15. Gradostroitel'stvo $v$ teni Stalina [Urban development in the shadow of Stalin, Kh. Bodenshatts, K. Post (comp.). Verlagshaus Braun-SCIO Media Publ., 2015, 416 p.

16. Kryukov M.V. Chto i kak delaet APU. Istoricheskoe dlya sovetskoi arkhitektury soveshchanie [What the APU does and how. Historical meeting for Soviet architecture]. In: Stroitel'stvo Moskvy [Construction of Moscow], 1932, no. 10, pp. 4-5.

17. Shchusev A.V. Ploshchadi Triumfal'naya, 0khotnoryadskaya, Dvortsa tekhniki [Triumfalnaya square, Okhotnoryadskaya square, Palace of Technology. In: Arkhitektura SSSR [Architecture of the USSR], 1934, no. 2, pp. 14-16.

18. Zholtovskii I.v. Ploshchad' Sverdlova [Sverdlov square]. In: Arkhitektura SSSR [Architecture of the USSR], 1934, no. 2, p. 14.

19. Sobolev I.N. Tsentral'naya magistral' stolitsy preobrazuetsya [The Central highway of the capital is being transformed] In: Stroitel'stvo Moskvy [Construction of Moscow], 1932, no. 8-9, pp. 21-25.

20. Semenov V.N. Voprosy planirovki [Planning issues]. In: Akademiya arkhitektury [Academy of Architecture], 1935, no. 4, pp. 39-43.

21. Starostenko Yu.D. Problema ansamblya v sovetskom gradostroitel'stve 1920-1930-kh gg. v teorii i na praktike [The problem of ensemble in Soviet urban planning in the 1920s and 1930s in theory and practice]. In: Sovetskoe gradostroitel'stvo. 1917-1941 [Soviet urban planning. 1917-1941]. Moscow, Progress-Traditsiya Publ., 2018, 820 p., pp. 327-366.

Ткаченко Сергей Борисович (Москва). Кандидат архитектуры, академик РАХ. Профессор МАРХИ (Москва, ул. Рождественка, 11/4. МАРХИ). Эл. почта: sbt@sbtkachenko.ru.

Tkachenko Sergey B. (Moscow). Candidate of Architecture, Academician of the RAA. Professor of the Moscow Institute of Architecture (11/4 Rozhdestvenka st., Moscow, 107031. MARCHI).E-mail: sbt@sbtkachenko.ru. 